\title{
CONTROLLED VENTILATION DURING ANAESTHESIA IN SOME DOMESTIC AND EXOTIC ANIMALS
}

L. FIALA, P. GUBA ${ }^{2}$, MARIE HOJOVCOVÁ ${ }^{1}, J \cdot$ PODLAHA $^{3}$ and O. RIEBEL 2

1 Central State Veterinary Hospital, 61242 Brno

2 Department of Pathophysiology, Medical Faculty, University of J.E.Purkyne, Brno, and 2nd Surgery Clinic, Regional Health Center, Brno

Received July 25, 1984

\begin{abstract}
F 1 a 1 a L., P. G u b a, Mar 1 e Hojo vc o vá, J. P o d 1 a $h$ a, $0 . \mathrm{R} 1$ e b.el: Controlled Ventilation During Anaesthesia in Some Domestic and Exotic Animals. Acta vet.Brno, 56,1987: 157-166.

Eighty two small animals were narcotised and operated using controlled ventilation. The czechoslovak ventilator Chirolog 1 together with the adaptor Chirolog 4 and the anaesthesia machine were used for controlled ventilation during inhalation anaesthesia. In two cases only complications appeared due to faulty use of the apparatus. Anaesthesia with controlled ventilation enables operations in debilitated patients with metabolic acidosis in which narcosis with spontaneous respiration produces ventilation acidosis. By means of the controlled ventilation many complications can be prevented. The method described is especially useful for exotic animals endangered by stress and shock.
\end{abstract}

Anaesthesia, controlled ventilation, narcosis, respiratory bailure, Chirolog 1, Chirolog 4.

Some operations and serious injuries can be accompanied by respiratory fallure. The later appears in clinically healthy animals as well as in animals under stress when unfavourable stimuli act for a longer time. Artificial respiration does not provide sufficient ventilation. When in few minutes spontaneous respiration is not reestablished, the patient will not survive. Moreover, in ruminants the artificial respiration is contraindicated because of the possibility of aspiration of the contents from the forestomachs.

$\mathrm{K} 1 \mathrm{e} 1 \mathrm{n}$. (1978) stated in animals kept in dorsal recumbency a circulatory decrease by two thirds of minute volume. This fact caused a change of the ventilation perfursion ration and increased the minute ventilation requirements. The majority of anaesthetics cause respiratory hypoxia and depress mechanisms compensating tissue hypoxia and acidosis. In complicated or long lasting operations unsufficient anaesthesia should not be applied. Moreover the use of relaxants, blocking spontaneous respiration, is necessary. In some instances the use of the electric knife without myroelaxants can be impossible 
as marked muscle contractions appear. Some operations necessitate blocking of the abdominal wall and diaphragm by means of deep narcosis and myorelaxation (H u d e c 1970). The respiratory fallure then always follows.

$S \mathrm{~h}$ or $\mathrm{t}$ et al. (1981) used controlled ventilation for abdominal operations in horses and other large animals. Controlled ventilation is of great importance for successful results.

$\mathrm{K} 1 \mathrm{r}$ k b y (1982) in his article "Treatment of Respiratory Insufficiency Syndrome" distinguishes spontaneous, controlled and substitute ventilations. Sufficient oxygen supply of the organism during controlled ventilation as compared to spontaneous ventilation is pointed out.

The majority of anaesthetics, producing deeper anaesthesia and mild myorelaxation, depress markedly respiration due to their effects upon the respiratory centre and respiratory muscles (D $r$ a b $k$ o vá 1981). The lower frequency and deepened respiration during narcosis with spontaneous breathing does not reflect the actual state of ventilation and respiration. The ventilation and respiration insufficiency lead quickly to respiratory acidosis and hypoxia.

$B \circ u d a$ and $P$ a v 1 i c a (1970) found in healthy animals after inhalation anaesthesia a decreased blood $\mathrm{pH}$ parallel to deepening of narcosis. During deep Halothane anaesthesia with spontaneous respiration blood $\mathrm{pH}$ about 7.1 and $\mathrm{BE}$ about +2 , indicating serious respiratory acidosis, were noticed. It is known that at the blood $\mathrm{pH}$ value 7.0 marked decrease of tissue metabolic processes due to developing acidosis occurs. The blood $\mathrm{pH}$ value 7.0 means threat to life (M u s 1 et al. 1976). In animals, showing metabolic acidosis (blood $\mathrm{pH} 7.0$ ) due to pathological conditions (trauma, colic, intestinal obstructions), deep anaesthesia causes depression of respiratory compensation mechanisms, additional decrease of blood $\mathrm{pH}$ and respiratory failure. In this case controlled ventilation is the only matter of choice (N e j e d $1 \dot{y}$ 1974). According to $\mathrm{S} t \mathrm{e} f \mathrm{f} e \mathrm{y}$ (1977), the operation is then mostly unsuccessful. Maintenance of the internal medium equilibrium requires large quantities of fluids: about $60-801$ in a large animal intravenously. As a rule death of the animal is considered to be in connection with toxic effects of the anaesthetic or high patient's susceptibility to peritor tis. In fact the patient dies due to asphyxia and traumatic shock. During ins -icient anaesthesia shock develops as a sequel of a disturbance of blood acid-lase balance.

\section{Materials and Methods}

E $\mathrm{q} \mathrm{u} \mathrm{i} \mathrm{p} \mathrm{m} \mathrm{e} \mathrm{n} \mathrm{t}$. In the present work the ventilator Chirolog 1 (Fig.1), adaptor Chirolog 4 (Fig. 2) and the anaesthesia machine Chirana N6 (Fig. 3) were used. The ventilator Chirolog 1 is propelled by compressed air or oxygen.

The apparatus aspirates air from the surroundings through an orifice and filter in its hind part. According to values, set on the front panel, air is driven into the patient. In the upper part of the panel a manomete $:$ is placed measuring either positive (inspiration) or negative (expiration) pressure The left part of the panel (red) serves for the expiration. The first knob from above sets the expirium length, the second one from the pressure. The second knob is mostly not used as the filled thorax during abolition of the positive pressure causes spontaneous expiration by its elasticity. In a patient, having no lung damage or lung oedema, there is no need to set this value. On the contrary, the value set to more than $2 \mathrm{kPa}$ leads to more intensive expiration of air from the lungs, damage of the alveoli, lung oedema and bleeging from the airways. The right part of the panel (green; serves for inspiration. The upper knob sets the inspiration length, the lower one the pressure. In 
order to overcome the thorax elasticity the minimum pressure value, $1.2 \mathrm{kPa}$ for inspiration should be set. The pressure ahould not exceed $3.5 \mathrm{kPa}$ for a longer period because of danger-of lung emphysema. Two yellow knobs control the assistor. By means of the assistor the activity of the apparatus can be changed according to air requirements of the patient preventing thus asphyxia. The left knob switch in, the right one tunes the sensibility. The safety pressure valve in the left part of the panel prevents damage to the lung tissues due to excessive inspiration. At the beginning the value $3.5 \mathrm{kPa}$ is advisable for prevention of lung emphysema. Excess air may escape through the valve. On the right from the valve there is an orifice for a tube. At the other end of the later a block of valves is placed. The opening in the block of valves serves for placement of the endotracheal cannula or for connection with Chirolog 4. In the lowest part of the panel openings for tubes from various sensors are situated (expiration, inspiration, pressure, negative pressure, assistor). The respiration values $\mathrm{e} . \mathrm{g}$. the respiration frequency and minute volume can be stated according to the size of the patient from a nomogram or from a spirometer incorporated into the inspiration cycle.

The Chirolog 4 represents a corrugated bag that is divided by a membrane into upper and lower parts. By means of it respiration impulses, provoked by the Chirolog 1 , can be transmitted to the inhalation narcotisation cycle anaesthesia machine N6. The upper part of the bag of the Chirolog 4 is filled with air according to frequency and pressure values setting on the Chirolog 1. The lower part of the bag, separated by a membrane from the upper part, is incorporated into the cycle of the anaesthesia machine instead of the respiration bag. The lower part of the bag is exactly controlled by the upper part by means of the membrane In this way the flow of the narcotisation mixture can be performed in the anaesthsia machine cycle according to settings on the ventilator Chirolog 1. The description of the anaesthesia machine N6 may be unnecessary as the machine is similar to VATRA apparatuses well known in veterinary practice. Fig. 3 shows the complete arrangement of apparatuses for controlled ventilation with inhalation anaesthesia. For intravenous or intramuscular anaesthesia only the Chirolog 1 apparatus for controlled ventilation is needed.

$\mathrm{N}$ a $\mathrm{r}$ c o s i s. Chlorpromazine $(0.2 \mathrm{mg}$ per $\mathrm{kg} \mathrm{b.m.i.m.)}$ and atropine $(0.1 \mathrm{mg}$ per $\mathrm{kg}$ b.m.i.m.) were used for premedication. 15 minutes later Thiopental $(15-20 \mathrm{mg}$ per $\mathrm{kg} \mathrm{b} . \mathrm{m}$.) was given intravenously. In carnivores a mixture of Ketalar ( $15 \mathrm{mg}$ per $\mathrm{kg}$ b.m.i.m.) and Rompun ( $1 \mathrm{ml}$ of a 2 \& solution per $10 \mathrm{~kg} \mathrm{b.m.i.m.)} \mathrm{was} \mathrm{applied} \mathrm{in} \mathrm{some} \mathrm{cases.} \mathrm{After} \mathrm{about} 15$ minutes narcosis was produced. Narcotised animals with spontaneous respiration were intubated, anaesthesia was deepened up to the respiratory arrest and controlled ventilation was started.

Two methods of ceepening and maintenance of narcosis were adopted. During the intravenous anaesthesia $100 \mathrm{mg}$ doses of Thiopental were repeatedly injected according to the need. Ventilation was controlled directly by the Chirolog 1 .

For the inhalation anaesthesia the anaesthesia machine N6, adaptor for controlled ventilation (Chirolog 4) and ventilator (Chirolog 1) were used. The inhalation mixture consisted of $25-50 \% \mathrm{O}_{2}, 50+75 \% \mathrm{~N}_{2} \mathrm{O}$ and $0.5-48$ Narcotan.

In order to achieve complete muscular relaxation Succinylcholine iodide in unusual high doses ( $1-2 \mathrm{mg}$ per $\mathrm{kg} \mathrm{b.m.)} \mathrm{were} \mathrm{repeatedly} \mathrm{injected}$ during the course of the operation.

As in various species of animals the duration of recurarisation after the application of Succinyl choline iodide may vary, the repeated doses depend 


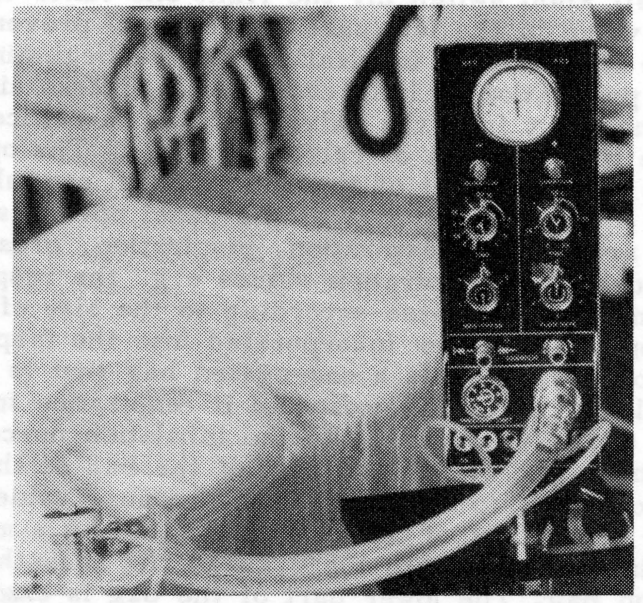

Fig. 1. The Chirolog 1 serving for controlled ventilation only.

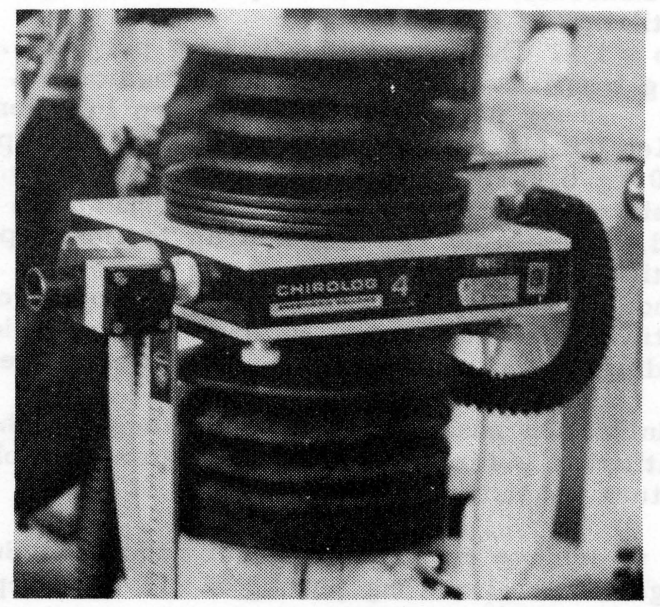

Fig. 2. The Chirolog 4 transmitting the respiratory impulses of the Chirolog 1 to the cycle of the anaesthesia machine. 
upon the anaesthetist. In majority of cases a cannula, was placed into the saphenous or jugular veins enabling application of remedies, anaesthetics, solutions and taking blood samples for $\mathrm{pH}$ measurements. In some animals monitoring of EKG and central venous pressure were performed. The acid-base balance, using the Astrup's method, was stated as well. As low concentrations of $\mathrm{N}_{2} \mathrm{O}$ produce light anaesthesia only and consciousness remains substantially unaffected, high concentrations $(50-75$ \&) were applied. In lower concentrations $\mathrm{N}_{2} \mathrm{O}$ acts as an inert gas being unchanged eliminated from the body by the lungs ( $W$ e $n k$ et al. 1983).

A $\mathrm{n} \mathrm{i} \mathrm{m} \mathrm{a} 1 \mathrm{~s}$. Experimental animals of the Faculty of Medicine (53 dingos, 8 goats, 4 pigs, 7 calves) and animals from the Zoological Garden ( 2 lynx, 1 hyena, 2 servals, 2 nasua spec.) were at disposal for general anaesthesia.

I $n t u$ b a $t$ i o $n$. In all animals endotracheal intubation followed the intravenous or intramuscular anaesthesia. It was found to be easy in carnivores and monkeys (direct placement of the tube without a laryngoscope). In pigs a $40 \mathrm{~cm}$ long adapted laryngoscope had to be used. In small ruminants intubation can be greatly facilitated by the use of a $50 \mathrm{~cm}$ long aluminium wire stylet protruding $6 \mathrm{~cm}$ from the endotracheal tube.

$R$ e c o v r y f r o m a n a s the $\mathrm{s}$ a. The change of controlled ventilation to spontaneous breathing follows the interruption of anaesthetic supply in the course of the operation. The assistor of the Chirolog 1 should be set to maximum sensibility. From this moment the apparatus follows the patient's respiration. The respiration frequency of the patient and the apparatus are characterized by marked irregularities. The later indicate recovery of the patient and spontaneous breathing. Then the apparatus should be disconnected from the endotracheal tube and the patient allowed to breathe spontaneously few minutes through the tube. When regular and sufficient respiration is noticed extubation follows. A thin rubber tube placed into the nasal cavity for oxygen supply is advisable. Recovery will be quicker and the patient able to move from the operation theatre.

A $f \mathrm{t} e r$ a $r$ e. In all kinds of narcosis disturbances in the internal medium and acid-base balance develop. In order to diminish them a $15 \%$ solution of calcium chloride ( $1 \mathrm{ml}$ per $10 \mathrm{~kg} \mathrm{b.m.)}$ was injected intravenously in the course of anaesthesia. Improvement of blood pressure and heart activity follows immediately. Simultaneously, a $4.2 \%$ solution of carbonic natrium hydrogen ( $1 \mathrm{ml}$ per $\mathrm{kg} \mathrm{b.m.)} \mathrm{was} \mathrm{applied} \mathrm{in} \mathrm{order} \mathrm{to} \mathrm{achieve} \mathrm{the} \mathrm{blood} \mathrm{pH}$ value near 7.4. Examination of blood $\mathrm{pH}$ should be done every 30 minutes during the operation. The aforementioned doses for maintenance of acid base balance have to be repeated.

\section{Results}

In most animals experimental or therapeutic operations, lasting 3 - $u$ hours, were performed íhilateral reconstruction of carotid or femoral arteries, abdominal aorta, implantation of bone grafts, bone operations, implantation of tooth roots, cryodestruction of the parotid gland, extirpation of neoplasms, laparotomies and operations of injuries). No complications due to anaesthesia were noticed. Recovery from Thiopental narcosis lasted $1-2$ hours and patients were then able to move. On the contrary, recovery from Thiopental anaesthesia with spontaneous respiration appeared only after $15-24$ hours. Recovery from inhalation anaesthesia was noticed already on the operation table and the animals were able to walk as well. In one case a dingo died due to faulty placement of the endotracheal tube into the oesophagus. In 


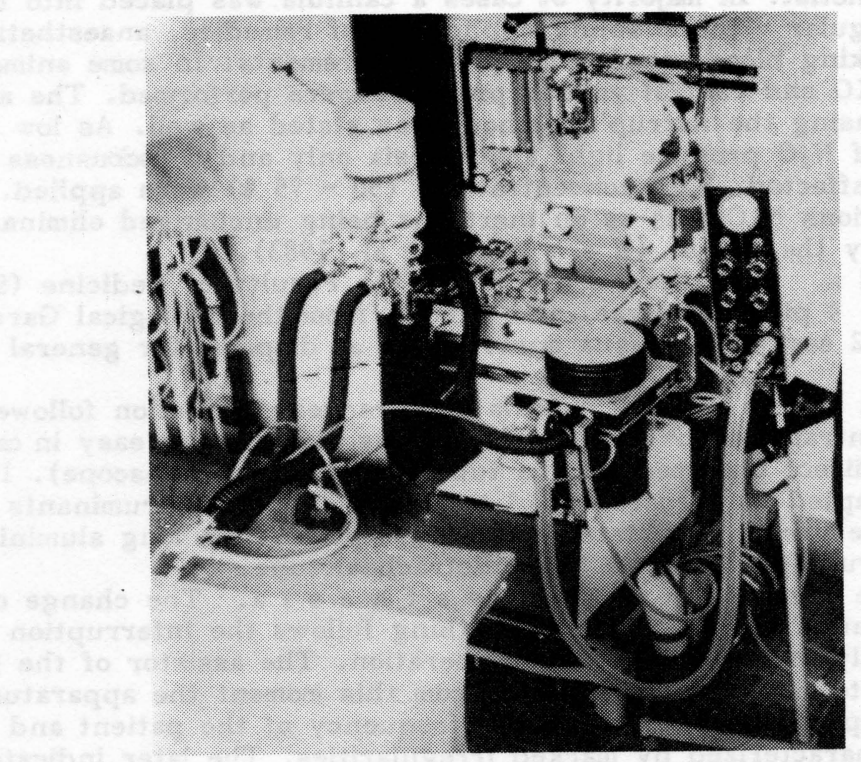

Fig. 3. The complete set for anaesthesia with controlled ventilation- the anaesthesia machine $\mathrm{N} 6$, the adaptor Chirolog 4 and the ventilator Chirolog 1 .

another case anaesthesia had to be interrupted for technical reasons and renewed after about one hour. The additional dose of Thiopental caused a prolonged recovery of 24 hours.

\section{Discussion}

The described method of controlled ventilator during narcosis enables performance of long lasting operations without danger of toxic effects of anaesthetics. In human surgery it represents a routine method $(\mathrm{H} \mathrm{u} \mathrm{d}$ e $\mathrm{c}$ et al. 1970; M u s i l et al. 1976; D r á b k o vá et al. 1981). It should be considered as an useful method in veterinary surgery as well. There are some variations in the intubation caused by anatomical differunce in various species of animals. High doses of myorelaxants may be applied without danger of respiratory failure. The possibility of development of post-anaesthetic complications is minimal and the consumption of anaesthetics decreased. The method allows to perform operations in debilitated patients in which anaesthesia with spontaneous ventilation would aggravate the state and even cause death immediately after the operation. Deep anaesthesia and relaxation enables the use of the electric knife without muscular contractions. In long lasting operations the blood $\mathrm{pH}$ examination indicated that the afore-mentioned medication for the maintenance of the acid-base balance every 30 minutes has been a necessity The course of anaesthesia and the duration of the recovery period remained unaffected. 


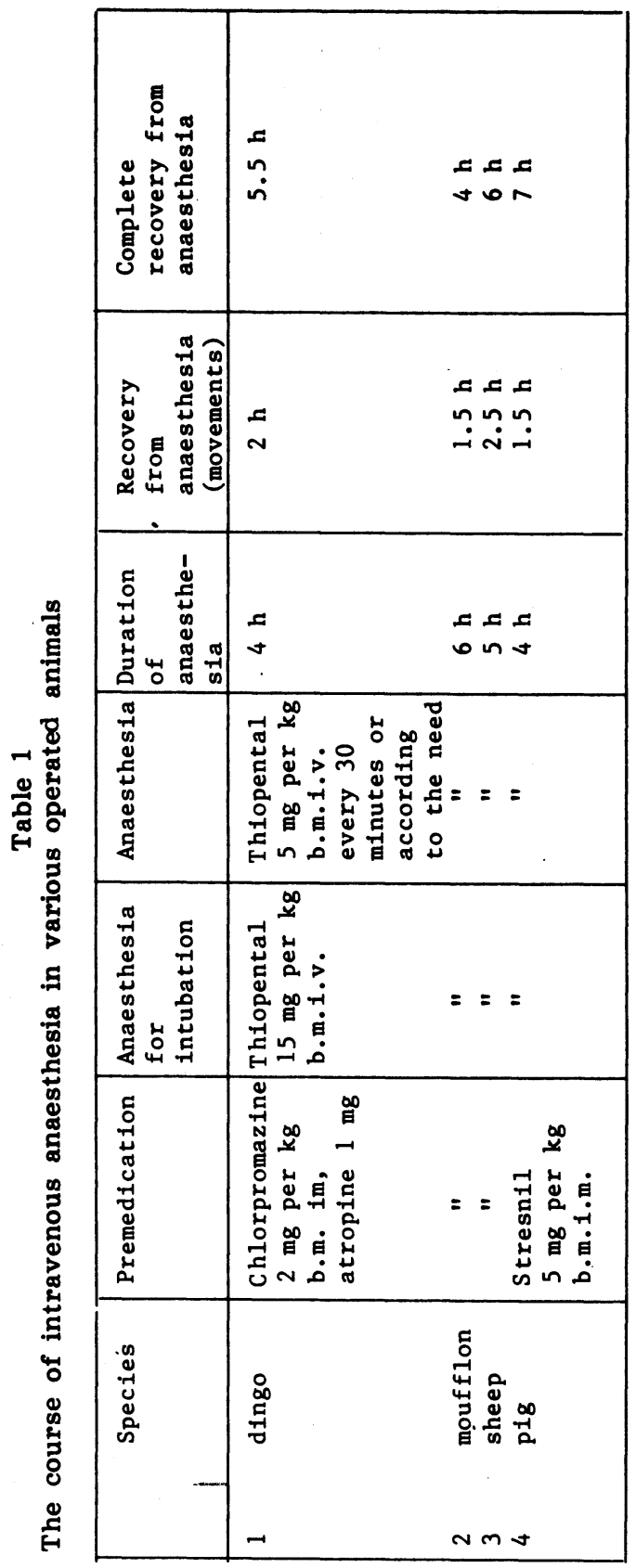




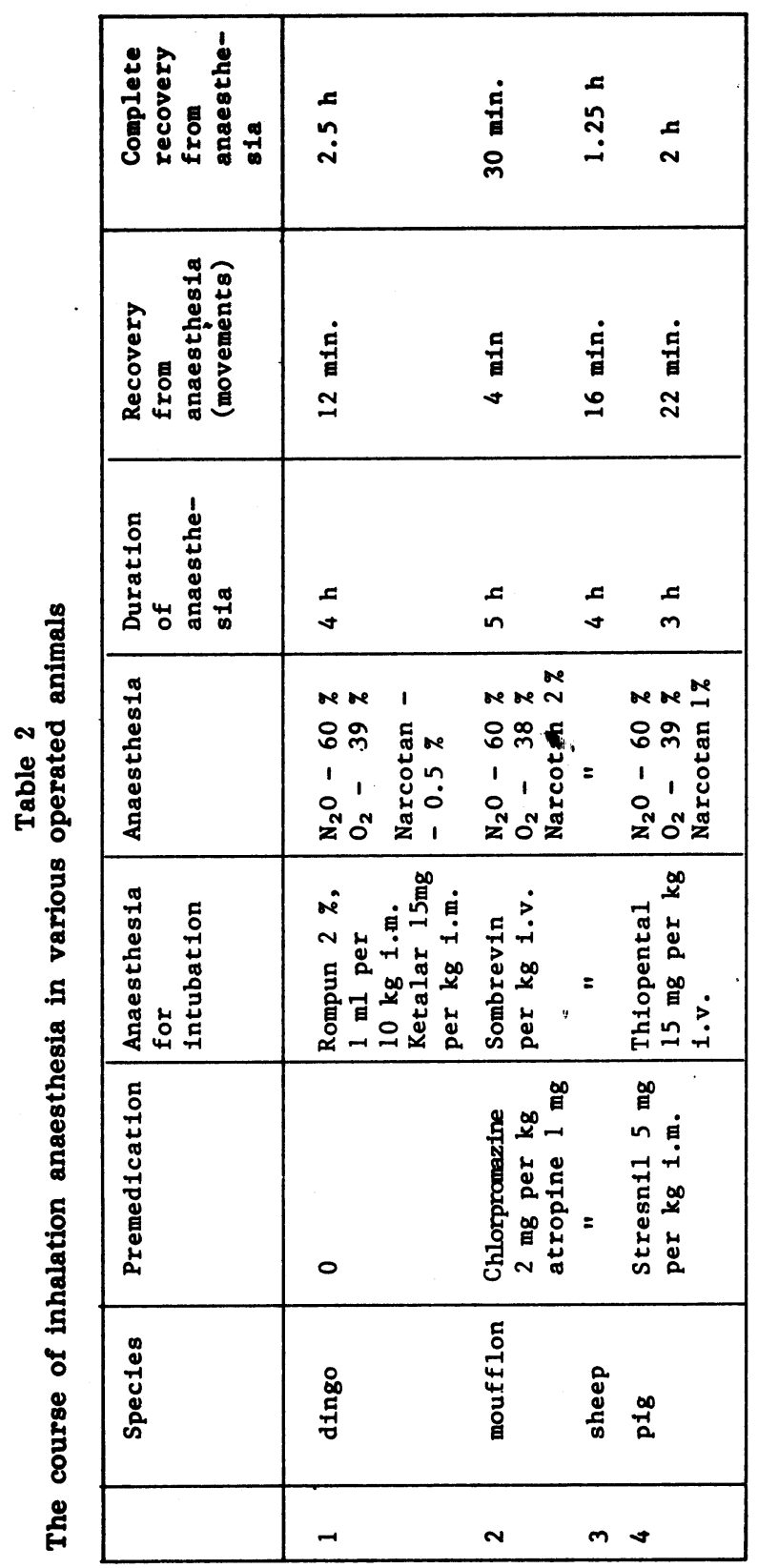




\section{Rízená ventilace płi narkóze některých domácich a exotických zviřat}

Pomocí łizené ventilace bylo narkotizováno a operováno 82 malých zvirat. $K$ Hizené ventilaci jsme použili $\chi_{s}$. ventilátor Chirolog 1 , který $s$ adaptérem Chirolog 4 lze ve spojení s narkotizačním př́strojem použit $i k$ inhalační narkóze.

Pouze ve dvou płripadech došlo ke komplikacím, které však nebyly zpúsobeny rízeniou ventilací, ale technickou závadou na přistrojích. Narkózou $s$ rizenou ventilaci lze operovat pacienty s těžkým narušením stavu, jako jsou pokrocilá stadia pyometry, torse $\chi_{i}$ invaginace střev apod., při kterých je pacient $v$ metabolické acidóze a pr̆i narkoze se spontánním dýcháním dochází navíc $k$ acidóze ventilační. Rízenou ventilací při narkóze přebírá anesteziolog odpovědnost za vnitřní prostředí pacienta a daleko účinněji múže zasáhnout pr̈i výskytu jakýchkoli komplikací.

Metoda $\mathrm{v}$ práci popsaná je významná při veterinárních zákrocích $u$ domácích, ale zejména u exotických zvírat, nebot̀ tato častěji podléhají stressu a šoku.

Управляемая вентиляция при нархозе нехоторых домашиних и эхзотических животных

С помощю управляемой вентилации наркотизировали и оприровали 82 животных. Для управляемой вентилации применяли чехословацкий вентилятор Хиролог 1, который с адаптером Хиролог 2 можно в соединении с нархозным аппаратом использовать для ингаляционного наркоза.

Только в двух случаях имели место осложнения, которые не были вызваны управляемой вентиляцией, а тецхническими неполадками аппаратуры. Наркозом с управляемой вентиляцией можно оперировать пациентов с тяжелым нарушением состояния, как например, далеко затедшие стадии пиометры, перехручивание или инвагинации кишечной петли и т.д., при хоторых пациент находитця в метаболичесхом ацидозе и при наркозе со спонтанным дыханием наступает вдобарох вентиляционный ацидоз. Управляемой вентиляцией при нархозе анестезиолог берет на себя ответственность за внутренную среду пациента и может гораздо еффективнее предпринимать меры при наличии любых осложнений.

Опицанный в работе метод весьма важен при ветеринарных вмешательствах у домашиь и, и, в осовенности, экзотических животных, попадающих чаще всего в стрессовое и шоковое состояние.

\section{References}

BOUDA, J. - PAVLICA, J.: Acid - base changes in the blood of cows during halothone narcosis. Acta vet. Brno 39, 1970: 265-270.

DIETZ, 0. - WIESNER, E.: Handbuch der Pferdekrankheiten für Wissenschaft und Praxis. Teil I., II., 1. vyd. Berlín 1981: 124-138.

DRABKOVA, J. a kol.: Základy anesteziologie. 1. vyd., Avicenum, Praha 1981: $360 \mathrm{p}$.

HUDEC, J. - STEINER, P. - HURAJ, E.: Órazová chirurgie. 1. vyd., Osveta, Martin 1970: 183-191. 
KIRBY, R.: Treatment of adult respiratory distress syndrome- ARDS. Seminar in anest. 1. vyd. 1982-4: 312-322.

KLEIN, H. - CLEVERT, H.: Pulmonary gas exchange in the calf with total artifictal heart. European surgical Research 8 suppl. 2, 1976: 25-26.

MUSIL, J. - NOVAKOVA, 0. - KUZ, K.: Biochemie v obrazech a schématech. 1. vyd. Avicenum, Praha 1976: 53-72.

NEJEDLY, B.: Vnitřní prostředí, klinická blochemie v praxi. 1. vyd. Avicenum, Praha 1974: 226 p.

SHORT, E. - BLAIS, D. - GLEED, R.: Small animal clinical equine practice. Cornell University Press, New York 1981: 65-97.

STEFFEI, E.: Anestetic management of abdominal surgery in the horse intraoperative supportive therapy. Am. J. Vet. 4, 9 roč., 1977: 49-53.

WENKE, M. - MRAZ, M. - HYNIE, S.: Farmakologie pro lékaře I. 1. vyd. Avicenum, Praha 1983: 124-143. 